\title{
50 Years of European Integration
}

Fifty years ago, the first issue of Intereconomics was published. In honour of this anniversary, many top European and international economists have contributed papers to this Forum, which looks back on five decades of European integration - from the early days of the European Economic Community to the lingering effects of the recent financial crisis. The contributions also look ahead to what the future holds for the European Union, covering issues as diverse as global trade, the future of the euro, reviving economic growth, the impact of demography and international relations.

Europe's Place in the Global Economy - What Does the Last Half Century Suggest for the Future?

Mikkel Barslund, Centre for European Policy Studies, Brussels, Belgium.

Daniel Gros, Centre for European Policy Studies, Brussels, Belgium.

Why Did Europe Decide to Move to a Single Currency 25 Years Ago?

Niels Thygesen, Professor emeritus, University of Copenhagen; Denmark; and Member of the Delors Committee on EMU, $1988-89$.

On the Relation of Monetary and Political Union

Otmar Issing, Goethe University Frankfurt, Germany.

The Eurozone's Flaws Are Not Intrinsic

Simon Wren-Lewis, Oxford University, UK.

Minimal Conditions for the Survival of the Euro

Barry Eichengreen, University of California, Berkeley, USA.

Charles Wyplosz, Graduate Institute, Geneva, Switzerland; and Centre for Economic Policy Research, London, UK.

\section{A Strategy Change for Europe: Old Myths Versus New Roads}

Karl Aiginger, Austrian Institute of Economic Research (WIFO), Vienna, Austria.

What Future for the EU in the Global Trading System?

Pascal Lamy, President emeritus, Jacques Delors Institute, Paris, France; and Director-General of the World Trade Organization, 2005-13, Geneva, Switzerland.

Europe and China in the Global Economy in the Next 50 Years: A Partnership for Global Peace and Stability

Li-Gang Liu, Peterson Institute for International Economics, Washington DC, USA. 